\title{
Development of technologies for large scale production of titanium and magnesium metals at the Defence Metallurgical Research Laboratory, Hyderabad
}

\author{
R B SUBRAMANYAM* and C V SUNDARAM ${ }^{+}$ \\ Defence Metallurgical Research Laboratory, Kanchanbagh, Hyderabad 500058, India \\ ${ }^{+}$National Institute of Advanced Studies, IISc. Campus, Bangalore 560012, India
}

\begin{abstract}
Titanium has been finding increasing usage as a structural metal in aerospace and many non-aerospace sectors mainly due to its light weight, high strength and outstanding corrosion resistance properties. India is very fortunate to possess the world's largest and richest mineral deposit for this metal. Early studies on the metal extraction during mid ' 60 s at the Bhabha Atomic Research Centre, Bombay and pilot plant studies at the Nuclear Fuel Complex. Hyderabad resulted in the establishment of a 'Technology Development Centre' at Defence Metallurgical Research Laboratory (DMRL). Hyderabad. DMRL has already demonstrated titanium sponge production feasibility in $2,000 \mathrm{~kg}$ batches by the conventional Krcll process and is presently engaged in the development of the more energy saving 'combined process technology' in $4,000 \mathrm{~kg}$ batches. Fused salt electrolysis is widely employed to produce magnesium metal in integrated titanium plants so as to regenerate magnesium from the by-product magnesium chloride. DMRL has developed magnesium electrolysis technology in a $30 \mathrm{kA}$ monopolar, modular type cell and is now developing the multipolar cell technology in $7 \mathrm{kA}, 22 \cdot 2 \mathrm{~V}$, two-module cell equipped with five bipoles in each module. This paper traces the developmental efforts on titanium metal extraction in India and describes the current efforts underway at DMRL for developing the latest energy efficient and cost effective technologies for the large scale production of both titanium and magnesium metals.
\end{abstract}

Keywords. Titanium; magnesium; production-technology-development; cost-effectivetechnology.

\section{Introduction}

Titanium is a metal with many unique properties such as high specific strength, excellent corrosion resistance to a wide range of acidic and alkaline media, outstanding corrosion and erosion resistance in sea water and brackish water, high fracture toughness even at cryogenic temperatures, total bio-compatibility and amenability to property tailoring through alloying additions and heat treatment. It is therefore not surprising that titanium and titanium alloys have established themselves as designers' choice for a wide range of industrial products and consumer durables. The beneficial properties of titanium as compared to many ferrous and non-ferrous metals and alloys have been exploited gainfully by industries such as aerospace, power generation, water desalination, chemical and electrochemical, paper and pulp, oil exploration and petrochemical etc. Bio-medical implants, sports goods, automotive, architecture, a wide range of consumer durables and costume jewellery can be cited among other areas where titanium has entered more recently.

The demand for titanium at least till very recently depended heavily on the aerospace sector in general, and the construction of military aircraft in particular. The latter, for obvious reasons, tends to fluctuate so heavily with the global pclitical scenario as well

*Author for correspondence 
as with the changing strategies of warfare like the shift from high speed aircraft to missiles etc. These vagaries in demand lead to establishment/closure of sponge plants at regular intervals starting from early ' 50 s and this process continues even till date. Currently the world sponge production capacity is estimated at 102,300 tons per year (TPY) (table 1)-a decline of $15 \%$ from peak capacity of 120,400 TPY in 1990 (Roskill information 1993). This presumes that the CIS capacity continues to be at 52,000 TPY although there are indications that a sizeable portion of this capacity is idling at present. Closure/suspension of production in some of the well established plants such as (i) The RMI Plant in the USA (1992), (ii) The Deeside Plant in the UK (1993) and (iii) The Showa Plant in Japan (1993/1994), presumably due to the dumping of accumulated stocks of CIS sponge in the European market at distress sale price after the break-up of the Soviet Union does indicate troubled times for titanium. However, it is expected that the demand for the metal in the developing countries, especially like India, will grow at a rapid pace and newer facilities will be established by the late '90s.

India possesses a substantial portion of the world's total ilmenite reserves, the principal raw material for titanium (table 2), bulk of which is exported as such without much value addition. This, coupled with the fact that titanium can substitute copper base and nickel base alloys in a majority of cases, makes up for a strong case for the early establishment of a titanium sponge plant in the country. (It is well known that India is not fortunate to possess any nickel bearing ores of exploitable grade and well over $50 \%$ of the copper requirement is met by imports). It is in this context that

Table 1. World titanium sponge production capacity $(000 \mathrm{~T})$.

\begin{tabular}{|c|c|c|c|c|}
\hline & 1985 & 1990 & 1992 & Process \\
\hline \multicolumn{5}{|l|}{$U S, A$} \\
\hline Timet & $12 \cdot 7$ & $12 \cdot 7$ & $12 \cdot 7$ & Mg.-Leach/Vac. Distill \\
\hline $\operatorname{RMI}(\mathrm{a})$ & $8 \cdot 6$ & $11 \cdot 0$ & $\mathrm{Nil}$ & $\ldots$ \\
\hline Oremet & $4 \cdot 1$ & $6 \cdot 8$ & 6.8 & Mg.-He Sweep \\
\hline Teledyne Wah Chang(b) & $1 \cdot 4$ & Nil & Nil & $\ldots$ \\
\hline \multirow[t]{2}{*}{ ITl(c) } & $2 \cdot 3$ & Nil & Nil & - \\
\hline & $29 \cdot 1$ & $30 \cdot 5$ & $19 \cdot 5$ & \\
\hline \multicolumn{5}{|l|}{ Japan } \\
\hline Osaka Titanium & $18 \cdot 1$ & $14 \cdot 4$ & $15 \cdot 0$ & Mg.-Vac distill \\
\hline Toho Titanium & $12 \cdot 0$ & $10 \cdot 8$ & $10 \cdot 8$ & -do- \\
\hline Nippon Soda(d) & $2 \cdot 0$ & $2 \cdot 0$ & $2 \cdot 0$ & Na.-Leach \\
\hline \multirow[t]{2}{*}{ Showa Titanium (e) } & $2 \cdot 0$ & 30 & $3 \cdot 0$ & Mg.-Vac distill \\
\hline & $34 \cdot 1$ & $30 \cdot 2$ & $30 \cdot 8$ & \\
\hline \multicolumn{5}{|l|}{$U K$} \\
\hline Deeside Titanium(f) & $5 \cdot 0$ & 5.0 & $5 \cdot 0$ & Na.-Leach \\
\hline USSR/CIS(g) & $48 \cdot 1$ & $52 \cdot 0$ & $52 \cdot 0$ & Mg.-Vac distill \\
\hline China & $2 \cdot 7$ & $2 \cdot 7$ & $3 \cdot 0$ & $\mathrm{Mg}-\mathrm{Vac}$ distill \\
\hline World's Total & $119 \cdot 0$ & $120 \cdot 4$ & $110 \cdot 3$ & \\
\hline
\end{tabular}

(a) Plant closed in 1992; (b) plant closed in 1987; (c) plant closed in mid 1987; (d) current position not known-Plant might be closed; (e) production suspended in early 1994; (f) plant closed in 1993; (g) currently (1994) significant cut back in production reported.

Estimated capacity in 1994 102,300 TPY

Capacity by Kroll process (1994) .. $\quad>98 \%$ 
Table 2. World reserves of ilmenite $1000 \mathrm{~T} \mathrm{TiO}_{2}$ content).

\begin{tabular}{|c|c|}
\hline Country & Reserves \\
\hline$\ldots-\cdots--$ & . \\
\hline India & 73.000 \\
\hline South Africa & 36.000 \\
\hline Norway & 32.000 \\
\hline China & 30,000 \\
\hline Canada & 27,000 \\
\hline Australia & 24.000 \\
\hline USA & 7,800 \\
\hline CIS & 5.900 \\
\hline Sri Lanka & 3,600 \\
\hline Total & 2.39 .300 \\
\hline
\end{tabular}

India's Share $(\%) 30.5$

Ref: Information in respect of countries other than India from Roskill, Economics of Titanium. Eighth Edition, 1993, Roskill Information Services, London. England. In case of India, information furnished by $\mathrm{M} / \mathrm{s}$ IRE Limited

the efforts underway at the Defence Metallurgical Research Laboratory (DMRL), Hyderabad to develop a commercially viable production technology for large scale production of titanium sponge assumes considerable significance.

Magnesium is one of the lightest structural metals and finds extensive usage in a wide range of industrial applications. Over $50 \%$ of virgin magnesium produced is utilized as alloying addition to aluminium to impart strength, toughness and many other beneficial mechanical properties. Desulphurization of steel, grain refining of cast iron, pyrotechnics, production of reactive metals like titanium, zirconium and uranium are some of the other conventional areas of application for the metal. More recently, however, there is a gradual switch-over from aluminium alloys to magnesium alloys for structural and automotive applications. Latest among the magnesium alloys are the magnesium-lithium alloys (some of them even lighter than water), which are finding increasing applications in the space sector for satellite components.

Production of magnesium is almost exclusively by fused-salt electrolysis of magnesium chloride derived from sea-water or brackish water from lakes. Around $22 \%$ magnesium is also produced by the ferro-silicon reduction of calcined dolomite (Pidgeon process) or by minor variants of this process.

Production of titanium by the Kroll process consumes large quantities of magnesium which ends up as magnesium chloride by-product. For improved economics, it has become a universal practice to recycle the by-product magnesium chloride through fused-salt electrolytic cells for the production of chlorine and magnesium, both of which are captively consumed---the former for the production of titanium tetrachloride from rutile and the latter for the reduction of chloride to sponge metal.

Realizing the importance of magnesium chloride recycle for efficient and economic production of titanium sponge by the Kroll process, a programme to develop the fused-salt electrolytic technology for magnesium production has also been undertaken at DMRL, Hyderabad. 


\section{Production technologies for titanium}

Commercial production of titanium commenced only in 1950 based on a process developed by Kroll on a pilot plant scale at the Boulder City (Nevada) Research Centre of the US Bureau of Mines. The process essentially consists of high temperature chlorination of rutile (a naturally occurring oxide mineral of titanium), purification of the raw $\mathrm{TiCl}_{4}$ from light and heavy fractions (low and high boiling impurities), magnesio-thermic reduction of pure chloride to sponge titanium in specially designed stainless steel reactors and separation of the by-product magnesium chloride and excess magnesium by vacuum distillation to obtain pure titanium sponge. Interestingly this process, developed by Kroll in the late ' 40 s, continues to be the dominant commercial route for titanium sponge production even after five decades - albeit with many innovative and improved features. From table 1 it can be seen that over $98 \%$ of sponge production today is by the Kroll process.

Production of titanium sponge on a limited scale has also been practised by the Hunter's process of sodio-thermic reduction of $\mathrm{TiCl}_{4}$ followed by aqueous leaching of the reduced mass. M/s RMI, USA and Deeside Titanium, UK have successfully operated this process on a commercial scale till very recently.

The third route for titanium sponge production is also based on pure $\mathrm{TiCl}_{4}$ as the starting material and involves fused salt electrolysis of $\mathrm{TiCl}_{4}$ in a mixture of alkali/alkaline earth chlorides. M/s Dow-Howmet, USA successfully operated a pilot plant based on fused salt electrolysis during the period 1980-1982 and claimed several benefits for the process in comparison to the Kroll and Hunter processes mentioned above. However due to sluggish growth in the demand for titanium, this plant closed its operation in 1982. On the basis of extensive investigations carried out on a pilot plant scale, M/s Electrochimica Marco Ginatta, Italy claimed production of superior quality titanium sponge at much reduced cost by their fused salt electrolytic process (Ginatta 1987). However, despite their best marketing efforts $M / s$ Ginatta could not successfully establish a commercial plant so far in any part of the world. M/s Ginatta's process however is attractive and quite possibly commercially viable. When the demand for titanium sponge picks up again, say by the late ' 90 s, some new capacity can perhaps be expected by their well-tested process of fused salt electrolysis in a fully automated plant.

\subsection{Early studies on titanium extraction at BARC and NFC}

During the period 1967-1973 a comprehensive programme in the field of extractive metallurgy of titanium was undertaken at the Bhabha Atomic Research Centre, Bombay (BARC). Starting with bench scale experiments on (i) static bed chlorination of rutile, (ii) batch type distillation equipment for $\mathrm{TiCl}_{4}$ purification and (iii) magnesium reduction of pure $\mathrm{TiCl}_{4}$ in $1 \mathrm{~kg}$ batches followed by pyro-vacuum treatment, the batch size for magnesio-thermic reduction and pyro-vacuum treatment (alternatively water/acid leaching) was enlarged to $15 \mathrm{~kg}$. Using the same equipment, the alternate route of sponge production by sodium reduction and water/acid leaching in $10 \mathrm{~kg}$ batches was also successfully demonstrated (Kulkarni et al 1969; Ahluwalia 1973). The data generated in BARC studies established the technical feasibility of both the routes for titanium sponge production with relative merits/demerits almost balancing each other in both the cases. With a view to gaining a meaningful insight into the 
techno-economic aspects of the Kroll's and Hunter's processes, as applicable to Indian conditions, a pilot plant of 7.5 TPY capacity was established at the Nuclear Fuel Complex, Hyderabad (NFC) with the following major equipment/facilities: (i) fluidized chlorinator of $500 \mathrm{~kg}$ per day capacity, (ii) batch type equipment for $\mathrm{H}_{2} \mathrm{~S}$ treatment and double stage distillation columns for chloride purification of matching capacity, (iii) magnesium reduction and pyro-vacuum treatment equipment with a batch capacity of $100 \mathrm{~kg}$ of titanium sponge, (iv) sodium reduction equipment (same as above with the addition of external feeding arrangement for liquid sodium) capable of producing around $60 \mathrm{~kg}$ per batch of titanium sponge, $(\mathrm{v})$ two-stage sodium reduction equipment with a capacity of $120 \mathrm{~kg}$ and (vi) necessary sponge handling and processing equipment.

Regular operation of the pilot plant during the period 1975-1978 gave valuable operating experience (Kulkarni et al 1980) on a sufficiently large scale to give meaningful results in regard to process selection under Indian operating conditions. Considering the consistently good quality of sponge and overall higher yields obtained by the magnesium reduction process, its ease and safety in operation as compared to the sodium reduction route, prevailing cost of reductants and possibility of recycling the by-product $\mathrm{MgCl}_{2}$ through fused salt electrolysis, it was concluded that the Kroll process of magnesium reduction followed by pyro-vacuum treatment will be best suited under Indian conditions and merits further investigation on still larger batch sizes.

The third route of fused-salt electrolysis was examined briefly at BARC in 1979 (Kulkarni et al 1980; Sridhar Rao et al 1980), but the results obtained were not very encouraging. Further, even if the quality of sponge could be improved by sustained efforts, scaling up of this technology to commercial level operation can pose serious engineering problems. The programme on fused-salt electrolysis was not therefore pursued further at that point of time.

\subsection{Titanium technology development at DMRL}

2.2a Kroll process $-2,000 \mathrm{~kg}$ batch: On the basis of the experience gained in the operation of the pilot plant at NFC 'A Technology Development Centre for Titanium Sponge' was established in the year 1984 at DMRL, Hyderabad with the specific objective of developing the Kroll process to a level of commercial viability (Subramanyam et al 1990). At this centre facilities were created for the following: (i) continuous purification of $\mathrm{TiCl}_{4}$ through two-stage distillation with a throughput of $150 \mathrm{~kg} / \mathrm{h}$ of chloride, (ii) Kroll reduction of pure chloride in $2,000 \mathrm{~kg}$ batches, (iii) pyro-vacuum treatment of reduced mass and (iv) crushing, grading and blending of sponge.

2.2b Chloride purification: $\quad \mathrm{Raw} \mathrm{TiCl}_{4}$ is purified by a two-stage distillation process for the elimination of dissolved gases like $\mathrm{O}_{2}, \mathrm{~N}_{2}, \mathrm{Cl}_{2}, \mathrm{HCl}, \mathrm{COCl}_{2}, \mathrm{COS}$, etc, low boiling impurities like $\mathrm{SiCl}_{4}, \mathrm{SnCl}_{4}, \mathrm{CCl}_{4}, \mathrm{CH}_{3} \mathrm{Cl}, \mathrm{CS}_{2}, \mathrm{SCl}_{2}$ etc and high boiling impurities such as $\mathrm{FeCl}_{3}, \mathrm{TaCl}_{5}, \mathrm{NbCl}_{5}, \mathrm{TiOCl}_{2}$, etc. Gaseous and low boiling impurities are eliminated in the first column (a carbon steel fractionating column of size $100 \mathrm{~mm}$ dia. $\times 4.7 \mathrm{~m}$ in height packed with stainless steel pall rings) by maintaining a reflux ratio of $8: 1$. From the reboiler of column-1, $\mathrm{TiCl}_{4}$ is continuously pumped into column-2 (a stainless steel packed column of $200 \mathrm{~mm}$ dia. $\times 2.55 \mathrm{~m}$ in height) which acts as a 'stripper' for distilling out pure $\mathrm{TiCl}_{4}$. 
Table 3. Typical operating conditions of the distillation column.

\begin{tabular}{llc}
\hline Feed rate & $:$ & $160 \mathrm{~kg} / \mathrm{h}$ \\
Distillate rate & $:$ & $5 \mathrm{~kg} / \mathrm{h}$ \\
Reflux rate & $:$ & $40 \mathrm{~kg} / \mathrm{h}$ \\
Bottom (product) rate & $:$ & $150-155 \mathrm{~kg} / \mathrm{h}$ \\
Reflux ratio & $:$ & $8: 1$ \\
Bottom temperature & $:$ & $138 \cdot 1^{\circ} \mathrm{C}$ \\
Top temperature & $:$ & $136 \cdot 5^{\circ} \mathrm{C}$ \\
Coiumn pressure & $:$ & $1-2 \mathrm{psig}$ \\
Sn level in bottom fraction & $:$ & $20-25 \mathrm{ppm}$ \\
Sn level in top fraction & $:$ & $200-250 \mathrm{ppm}$
\end{tabular}

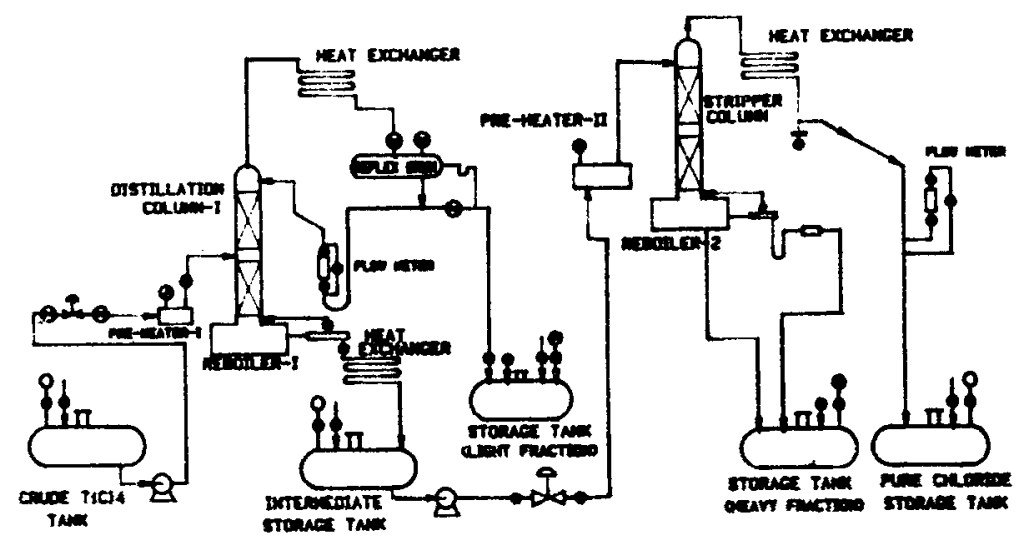

Figure 1. Schematic diagram of $\mathrm{TiCl}_{4}$ distillation set up.

With experience gained in the operation of the distillation units on the manual mode, all the field instruments have been progressively interfaced with a microprocessor based distributed control system (DCS) with a provision for the reboiler heaters being driven by the DCS through thyristor controlled drives for precisely adjusting the heat inputs. Substantial improvement in the stability of the distillation columns has been achieved after introducing computer control of all process parameters. In table 3 typical operating conditions of the fractionating column are listed. Figure 1 is a schematic of the distillation set-up at DMRL and figure 2 depicts a view of this facility.

2.2c Metal reduction and pyro-vacuum treatment: Pure titanium tetrachloride is reduced to sponge in $2000 \mathrm{~kg}$ batches using magnesium as reductant in a specially designed stainless steel reactor. The reduction is carried out at around $830-860^{\circ} \mathrm{C}$ and the system pressure is controlled in the pressure range of 0.15 to $0.35 \mathrm{~kg} / \mathrm{cm}^{2}(\mathrm{~g})$ by controlling the feed rate of $\mathrm{TiCl}_{4}$. Temperature control within the desired range is achieved by controlled air cooling of the 'Reactor' using a centrifugal blower in conjunction with computer controlled butterfly valves. Initially this reactor was provided with a high temperature, custom-designed and fabricated stainless steel 


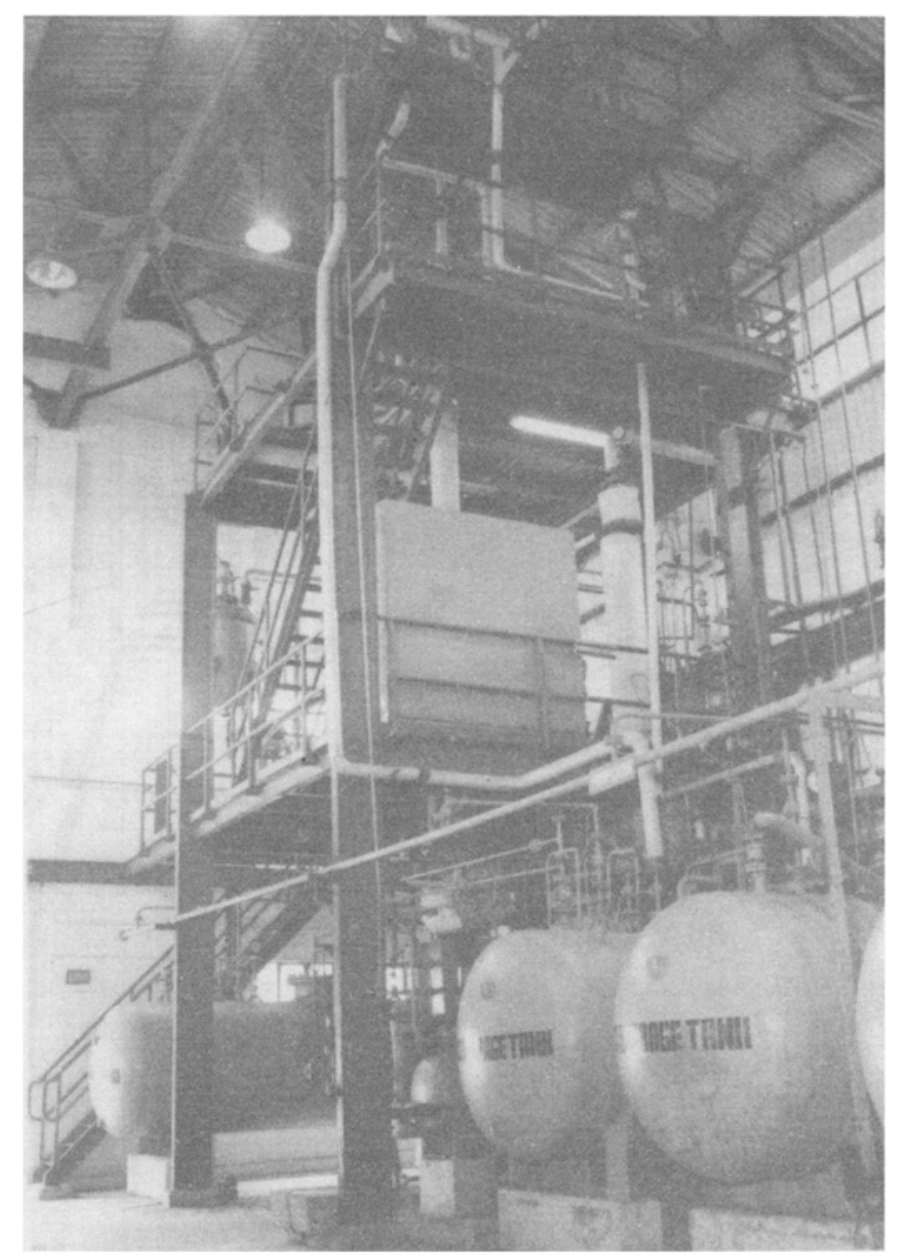

Figure 2. Chloride purification bay.

tapping valve at the bottom for the periodic removal of by-product $\mathrm{MgCl}_{2}$. Subsequently the system was converted to 'top tapping' for better safety in operation. Figure 3 depicts schematically the two arrangements. (In the bottom tapping arrangement, failure of the high temperature valve during reduction can lead to draining of substantial amounts of magnesium and magnesium chloride with consequent fire hazard).

With the experience gained in the operation of the Kroll process using conventional instrumentation, a programme to progressively switch over to microprocessor based DCS for precise control of all process parameters such as titanium tetrachloride feed rate, furnace temperatures control, air-supply control through pneumatically operated dampers (to remove the exothermic heat of reduction), control of argon admittance and bleeder valves (for maintaining the reactor pressure within the permissible limits). maintenance of argon back pressure in the 'top tapping' system etc has been successfully implemented with highly satisfactory results.

The reduced mass along with the crucible is pyro-vacuum treated in a separate unit at a temperature of $975^{\circ} \mathrm{C}$ under a dynamic vacuum in the range of $10^{-2}$ to $10^{-3} \mathrm{~mm}$ 

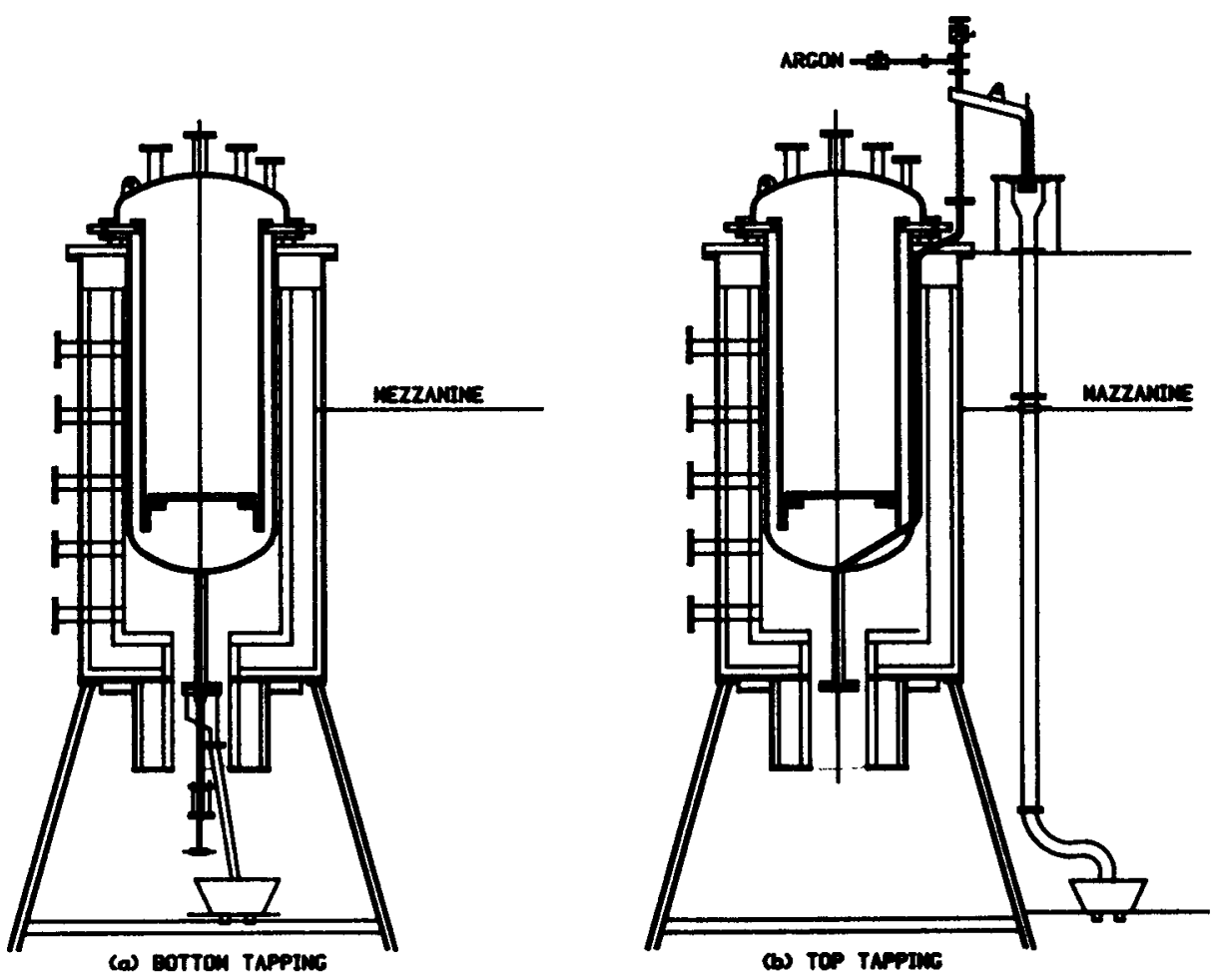

Figure 3. Schematic diagram of $\mathrm{MgCl}_{2}$ tapping arrangements.

Table 4. Typical process parameters $-2000 \mathrm{~kg} / \mathrm{batch}$.

\begin{tabular}{lc}
\hline Reduction: & \\
Excess magnesium & $30-40 \%$ \\
Temperature & $830-860^{\circ} \mathrm{C}$ \\
Reaction time & $24-30 \mathrm{~h}$ \\
$\mathrm{TiCl}_{4}$ feed rate & $300 \mathrm{~kg} / \mathrm{h}(\mathrm{Max})$ \\
$\mathrm{No}^{\circ}$ of tappings of $\mathrm{MgCl}_{2}$ & $12-16$ \\
Vacuum distillation: & \\
Temperature & Soak time \\
$300^{\circ} \mathrm{C}$ & $6 \mathrm{~h}$ \\
$700^{\circ} \mathrm{C}$ & $8-10 \mathrm{~h}$ \\
$975^{\circ} \mathrm{C}$ & $40-45 \mathrm{~h}$ \\
Ultimate vacuum & $10^{-3} \mathrm{~mm} \mathrm{Hg}$ (abs) \\
\hline
\end{tabular}

$\mathrm{Hg}$ (abs). On the basis of the experience gained over several production campaigns the operating conditions for reduction and pyro-vacuum treatment for a $2,000 \mathrm{~kg}$ batch have been optimized as shown in table 4 .

After pyro-vacuum treatment, the sponge cake is ejected out of the crucible in a. $160 \mathrm{~T}$ capacity horizontal hydraulic press. After cleaning the exterior surface, the sponge cake is crushed and graded into four fractions viz. top, side, centre and bottom on a $630 \mathrm{~T}$ hydraulic press (figures 4 and 5). Each of these fractions are separately crushed in jaw crushers to the finished size of $-20 \mathrm{~mm}$ to $+2 \mathrm{~mm}$, analysed and blended to 


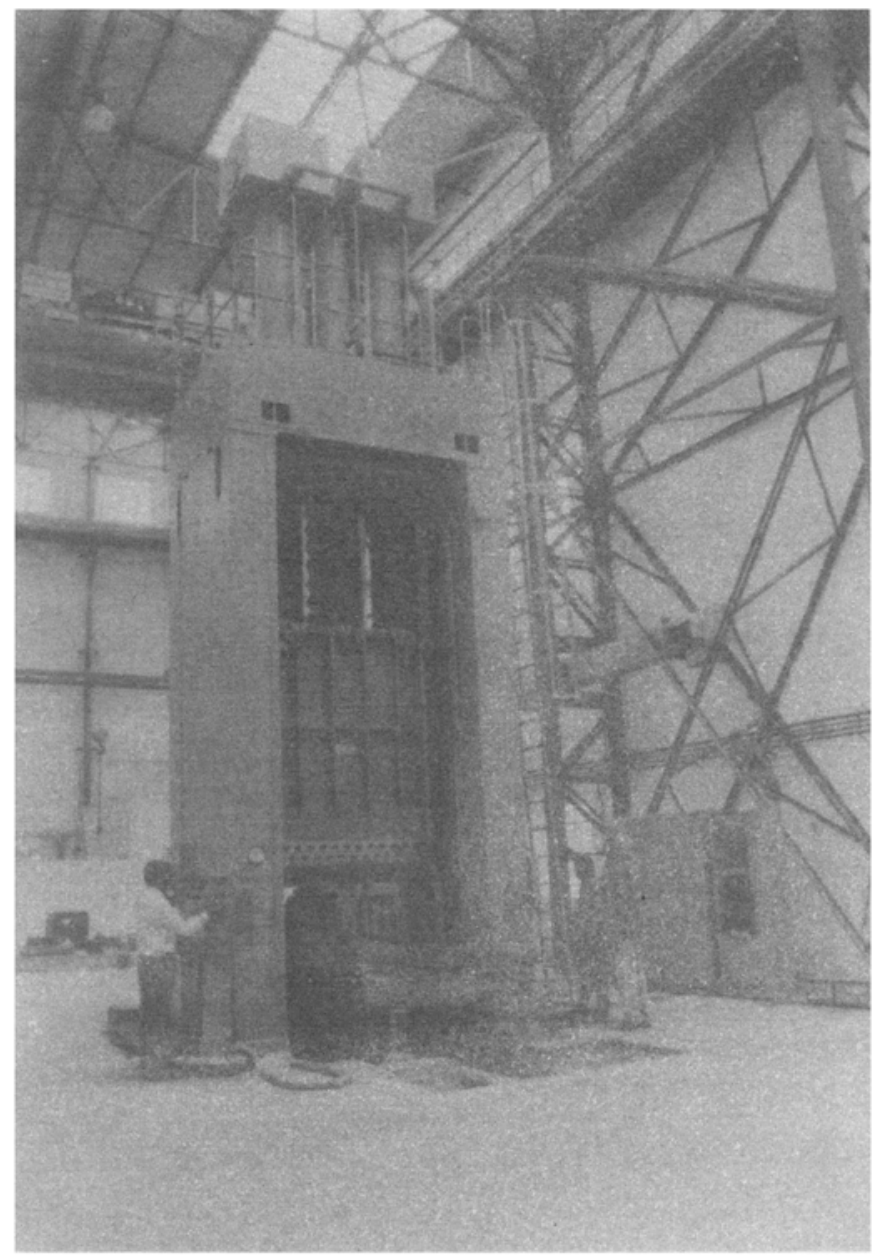

Figure 4. $630 \mathrm{~T}$ capacity hydraulic press.

specifications. Table 5 shows the typical analysis of titanium sponge produced on $2,000 \mathrm{~kg}$ scale at DMRL.

$2.2 \mathrm{~d}$ Combined process technology: In the conventional Kroll process, the reduced mass is cooled to room temperature and then transferred to the pyro-vacuum treatment unit for the subsequent separation process at high temperature under dynamic vacuum. Ever since the advent of the Kroll process, efforts were underway (Winter 1956) to combine the reduction and pyro-vacuum treatment operations into a single step process with a view to deriving the following advantages: (i) reduced overall cycle time (one cooling and heating cycle avoided), (ii) reduced energy consumption (partial/total elimination of one heating cycle), (iii) improved product quality (batch not exposed to atmosphere after reduction operation), (iv) reduced capital cost (only one furnace used for both reduction and pyro-vacuum treatment) and (v) reduced labour requirement (no unloading and re-loading after reduction). 


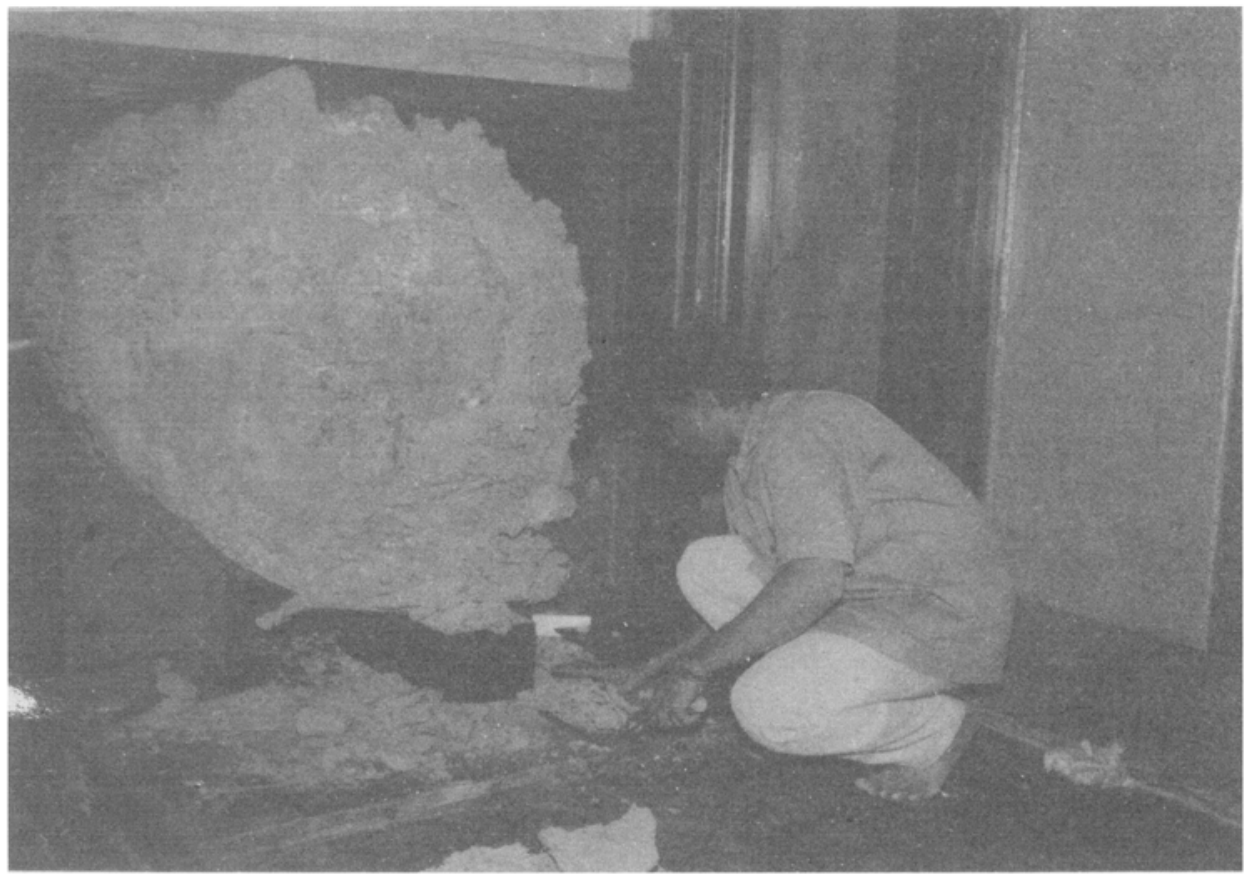

Figure 5. Crushing of sponge cake on $630 \mathrm{~T}$ hydraulic press.

Table 5. Typical quality analysis of titanium sponge cake $(2,000 \mathrm{~kg}$ batch).

\begin{tabular}{lccccc}
\hline & \multicolumn{5}{c}{ Analysis (wt. \%) } \\
\cline { 2 - 5 } Location & $\mathrm{O}_{2}$ & $\mathrm{~N}_{2}$ & $\mathrm{C}$ & $\mathrm{Fe}$ & \multirow{2}{*}{ Hardness (BHN) } \\
\hline Centre & 0.0866 & 0.0012 & 0.0031 & 0.0140 & 90 \\
Side & 0.0878 & 0.0041 & 0.0226 & 0.0940 & 153 \\
Bottom & 0.1300 & 0.2000 & 0.0170 & 0.3000 & 213 \\
\hline
\end{tabular}

The combined process essentially uses two reactors suitably interconnected-one placed within a specially designed furnace to carry out the reduction and pyro-vacuum treatment sequentially without involving intermediate cooling, unloading and reloading of the batch into a separate unit for pyro-vacuum treatment and the second retort placed within a condenser station to receive and condense the distillates of excess magnesium and trapped residual magnesium chloride during the vacuum treatment cycle. After completion of pyro-vacuum treatment, this second retort with further magnesium addition is used for the next cycle of sponge production. While the concept in principle appeared simple, the underlying engineering complexities eluded an industrially workable design for several decades.

The first notable success in this direction was reported by Osaka Titanium Company, Japan during the late ' 70 s (Noda 1988b). Osaka Titanium could successfully overcome the several problems associated with the combined process technology with innovative design and engineering concepts such as (i) the development of a high 


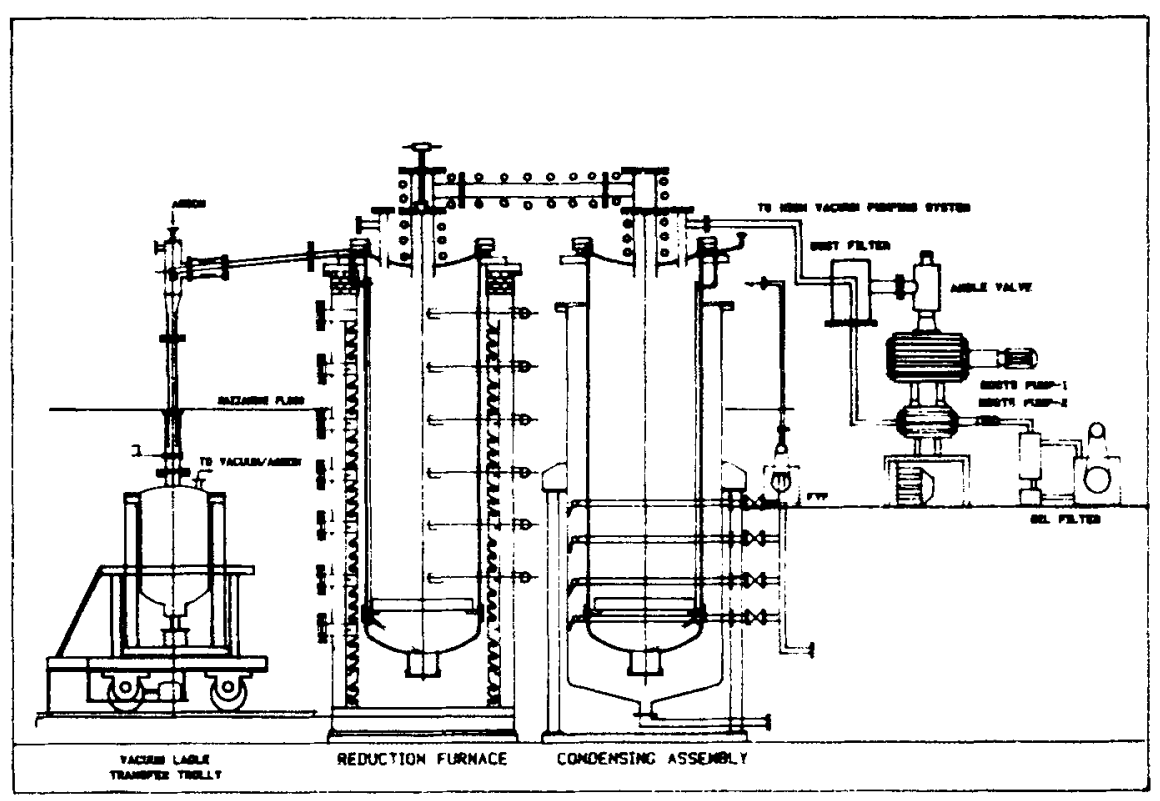

Figure 6. Schematic diagram of $4,000 \mathrm{~kg}$ combined unit assembly.

temperature, high vacuum valve to isolate the two reactors during the reduction stage, (ii) engineering of condenser reactor supporting system to provide for the free expansion of the interconnecting pipe and (iii) development of a dual purpose furnace to meet the air cooling requirements during the 'reduction cycle' and the vacuum requirements during the "vacuum treatment cycle', etc. Currently the combined process with minor variations is being practised by all the sponge producers in Japan, CIS and China with resultant savings in the cost of production.

2.2e Development of combined process technology at DMRL-4,000 kg batch: With a view to developing the cost-effective 'combined process technology' a new $R$ and D project was taken up at DMRL in 1992. The scope involved design, fabrication, installation and commissioning of equipment followed by optimization through computer control of all process variables for the production of titanium sponge in $4,000 \mathrm{~kg}$ batches.

The basic equipment (figures 6 and 7) comprises (i) a custom designed $480 \mathrm{~kW}$ pit type electric resistance furnace for carrying out reduction and pyro-vacuum treatment sequentially (with air-cooling facility to extract the exothermic heat during reduction and vacuum capability to enable operation under medium vacuum during the pyrovacuum treatment cycle, (ii) two numbers of specially designed stainless steel reactors identical in all respects except for the nozzles configuration in the lids, (iii) a high vacuum pumping system comprising two numbers of high capacity Roots Pumps and a oil rotary mechanical pump in series for retort evacuation and a separate set of vacuum pumps for furnace evacuation, (iv) a novel valveless top tapping system for by-product withdrawal, (v) a specially designed vacuum ladle for receiving the byproduct magnesium chloride and part of the excess magnesium during reduction and (vi) a custom designed DDCS along with computer compatible instrumentation, etc. 


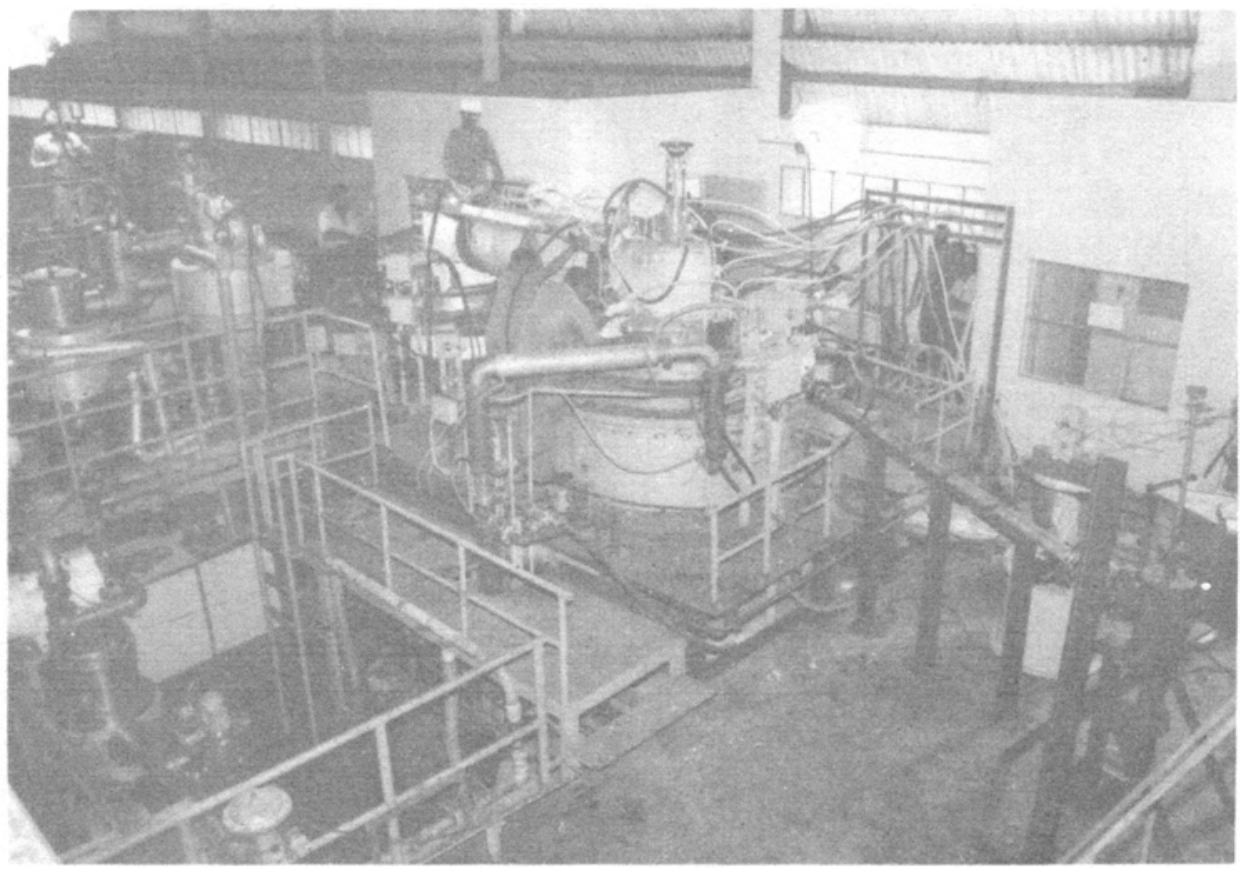

Figure 7. Combined process equipment (DMRL).

After carrying out reduction and pyro-vacuum treatment, the 'process reactor' containing sponge will be cooled in a cooling station and the sponge cake will be extracted using a $500 \mathrm{~T}$ vertical hydraulic press (figure 8). The sponge cake will be ejected into a separate vessel under argon atmosphere to eliminate possible fires due to friction.

The sponge cake will then be graded to four fractions (top, centre, side and bottom) on a custom designed $630 \mathrm{~T}$ hydraulic press (figure 5) equipped with a guillotine shear type tooling. Sponge pieces of approximately $150 \mathrm{~mm}$ size (the product from this press) will be further crushed through two numbers of toothed type double roll crushers in series and sized to $-20 / 25 \mathrm{~mm}$ to $+2 \mathrm{~mm}$ fraction. After analysing, a double cone blender will be used for making uniform quality sponge 'lot's for final packing in argon sealed $250 \mathrm{~kg}$ capacity drums.

All items of equipment (as described above) required for developing the combined process technology in $4,000 \mathrm{~kg}$ batches have been received, installed and commissioned. Individual sub-systems have been extensively tested for smooth and trouble free operation. The first trial production run was successfully completed recently with highly satisfactory performance of all the sub-systems and process controls. Titanium sponge cake weighing 4.3 T was ejected out from the reactor on 31 December 1994. Grading, size reduction and quality evaluation of sponge are being carried out.

\section{Technology development programmes on magnesium at DMRL}

With a view to establishing a viable route to recycling the by-product magnesium chloride generated in titanium sponge production, a programme to develop cost-effective 


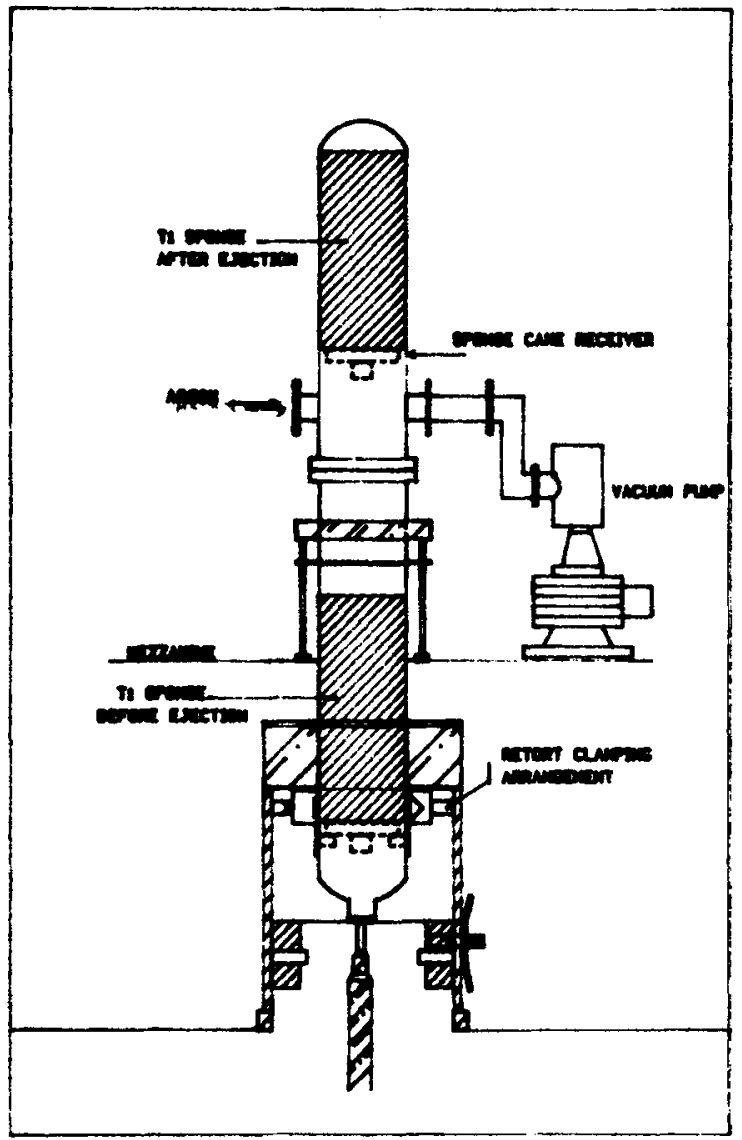

Figure 8. Schematic diagram of $500 \mathrm{~T}$ vertical ejection press.

fused-salt electrolytic cells was initiated at DMRL in the year 1984 with the active collaboration of the Central Electrochemical Research Institute, Karaikudi (CECRI). CECRI, based on extensive studies carried out on laboratory/pilot plant scales, developed a $8 \mathrm{kA}$ modular cell consisting of four members of $2 \mathrm{kA}$ modules. Extending this concept, a $30 \mathrm{kA}$ modular type cell comprising 12 module of $2.5 \mathrm{kA}$ each was designed, fabricated and assembled at DMRL as part of a joint technology development programme with CECRI.

The DMRL cell (figure 9) is essentially a rectangular steel shell internally lined with $70 \%$ alumina bricks. The cathode assembly consists of four fabricated steel structurals, assembled side by side so as to give 12 hexagonal openings in a $3 \times 4$ array. The anode assembly consists of 12 numbers of $150 \mathrm{~mm}$ diameter graphite rounds integrally mounted on a structural steel framework. When positioned over the cell body, the graphite rounds go through the hexagonal openings of the cathode assembly with an inter-electrode gap of $22-27 \mathrm{~mm}$. A hanging refractory curtain across the cell serves to separate the electrolytic zone from the non-electrolytic zone from where magnesium metal is ladled out at regular intervals. After optimizing the process parameters the cell was operated successfully for a continuous period of 85 days. Table 6 gives details on the cell operating conditions and the results obtained (Sekhar et al 1987). 


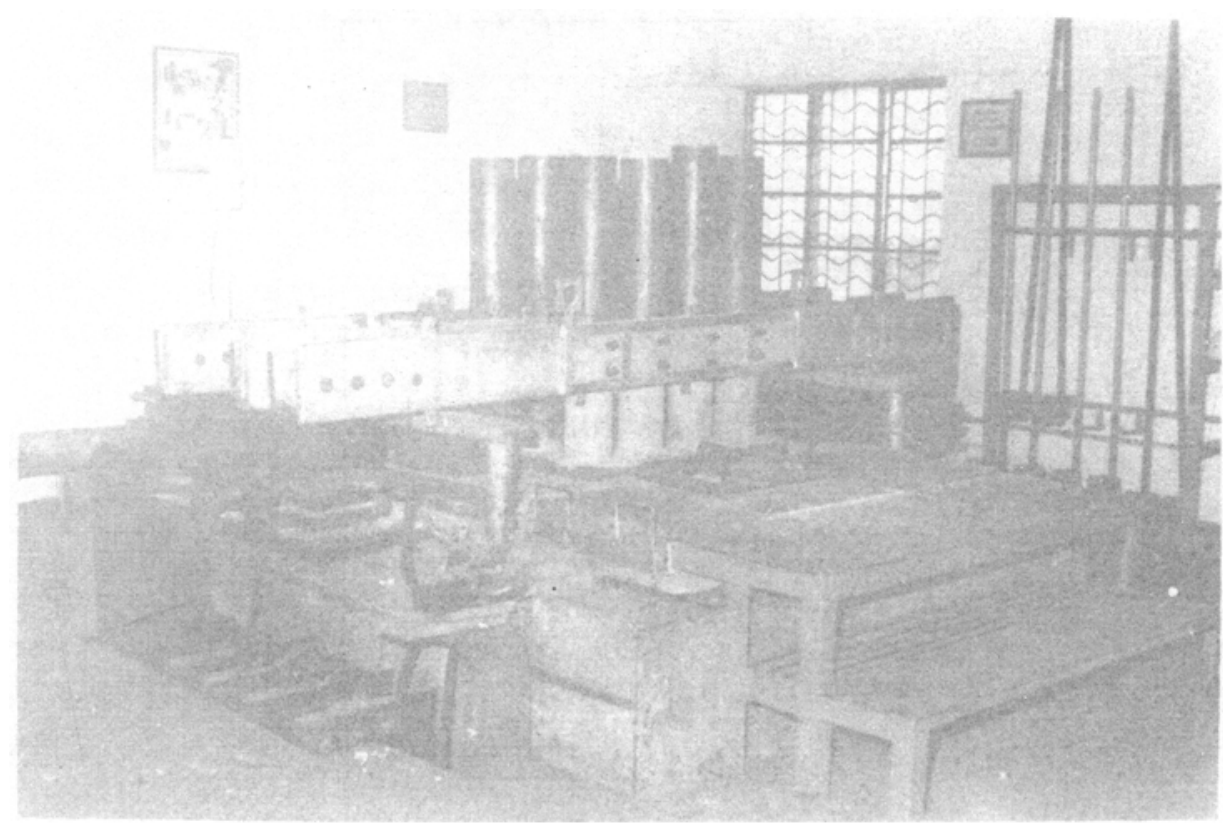

Figure 9. $30 \mathrm{kA}$ Monopolar cell (DMRL).

Table 6. Operating conditions of $30 \mathrm{kA}$ modular, monopolar cell (DMRL).

\begin{tabular}{lcc}
\hline Cell operating conditions & & \\
Current & $:$ & $20-30 \mathrm{kA}$ \\
Cell voltage & $:$ & $4.5-5.5 \mathrm{~V}$ \\
Operating temperature & $700-730^{\circ} \mathrm{C}$ \\
Bath composition (in wt.\%) & $: \quad 30 \% \mathrm{NaCl}^{2}, 30 \% \mathrm{KCl}$ \\
& & $20 \% \mathrm{BaCl}_{2}, 15 \% \mathrm{MgCl}_{2}$ \\
Results & $:$ & $70 \%$ \\
Average current efficiency & $:$ & $15-17 \mathrm{k} \mathrm{Wh} / \mathrm{kg}$ \\
Energy consumption (DC) & $:$ & $150 \mathrm{~kg}$ \\
Average metal output per day &
\end{tabular}

The above results are based on a total metal output of $12.8 \mathrm{~T}$ over 85 days of continuous operation of the cell.

\subsection{Multipolar cell development}

Years of painstaking research particularly by $\mathrm{M} / \mathrm{s}$ Alcan Limited, Canada in active collaboration with the Osaka Titanium Company, Japan (OTC) eventually lead to the establishment of the very first energy efficient multi-polar cell at the OTC in the year 1982 for recycling their by-product magnesium chloride (Noda 1988a). Parallely, the Ishizuka Research Institute, Japan had also developed this technology and established commercial size cells at the Showa Titanium Company, Japan in 1983 for recycling the by-product magnesium chloride (Ullman 1990). Prior to the development of the multipolar cell, the tapered anode cell developed by $\mathrm{M} / \mathrm{s}$ Alcan Limited and operated 
Table 7. Magnesium technology development.

\begin{tabular}{llrrr}
\hline SI. No. & Cell design & Year & Cell capacity & $\begin{array}{r}\text { Power consumption } \\
\text { (K Wh/kg) (DC only) }\end{array}$ \\
\hline 1. & I.G. Cell & 1930 & $60-120 \mathrm{kA}$ & $16-18$ \\
2. & DOW Cell & 1945 & - & $16-18$ \\
3. & ALCAN (Monopolar) & 1961 & $100 \mathrm{kA}$ & 18 \\
4. & ALCAN (Tapered Anode) & 1975 & $80 \mathrm{kA}$ & 14 \\
5. & DOW Cell Modified & 1978 & $180 \mathrm{kA}$ & $13-15$ \\
6. & NORSK Hydro Cell & 1978 & $350-400 \mathrm{kA}$ & $12-14$ \\
7. & ALCAN (Multipolar) & 1982 & $100 \mathrm{kA}$ & 10 \\
& (Osaka Titanium, Japan) & & & 10 \\
8. & ISHIZUKA Cell & 1983 & $50 \mathrm{kA}$ & \\
& (Showa Titanium, Japan) & & & \\
\hline
\end{tabular}
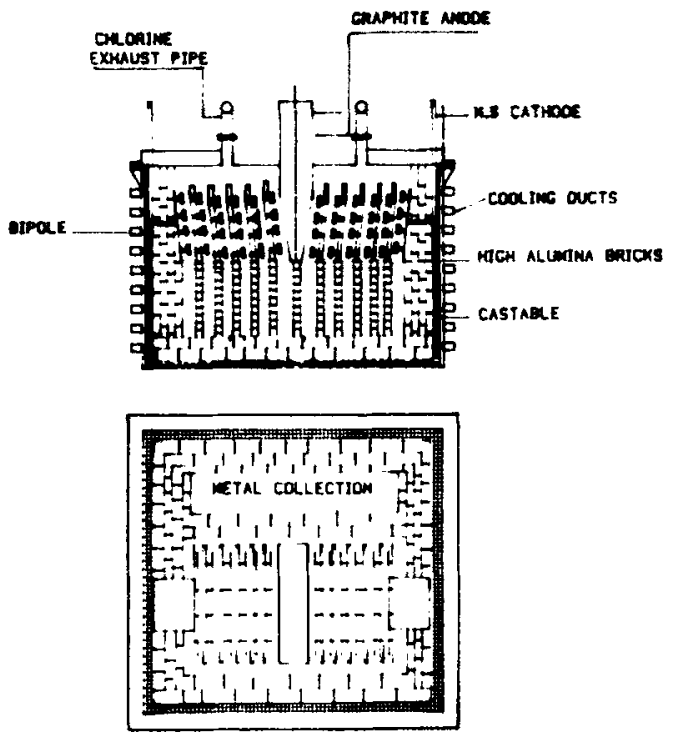

SALIENT FEATURES,

1. TKA $22.2 Y$ WULTIPOLAR CELL VITH TVO 3.5\%A MOOUES

2. EACH 3.S Ka moOULE HAS S Bimales

2. OESIGMEO METAL OUTPUT - ABOUT SN KgJOAT

Figure 10. Schematic diagram of $7 \mathrm{kA}$ multipolar cell (DMRL).

by the Osaka Titanium Company till 1982 (when they switched over to the multipolar cell) was considered as the ultimate in diaphragmless cell technology. In table 7 specific energy consumptions (DC only) of some of the industrially operated cells are compared.

With a view to deriving the benefits of the multipolar cell such as lower specific energy consumption and larger space-time yields, a $7 \mathrm{kA}, 2$ module cell with five bipoles in each module has been designed by DMRL (figure 10). This cell, with a central graphite anode and two steel cathodes at either end, has five specially designed spaced type graphite-steel bipoles in each module. The design permits effective circulation of the electrolyte between the electrolytic and the non-electrolytic zones (Srivastava et al 1994) and operation of the 

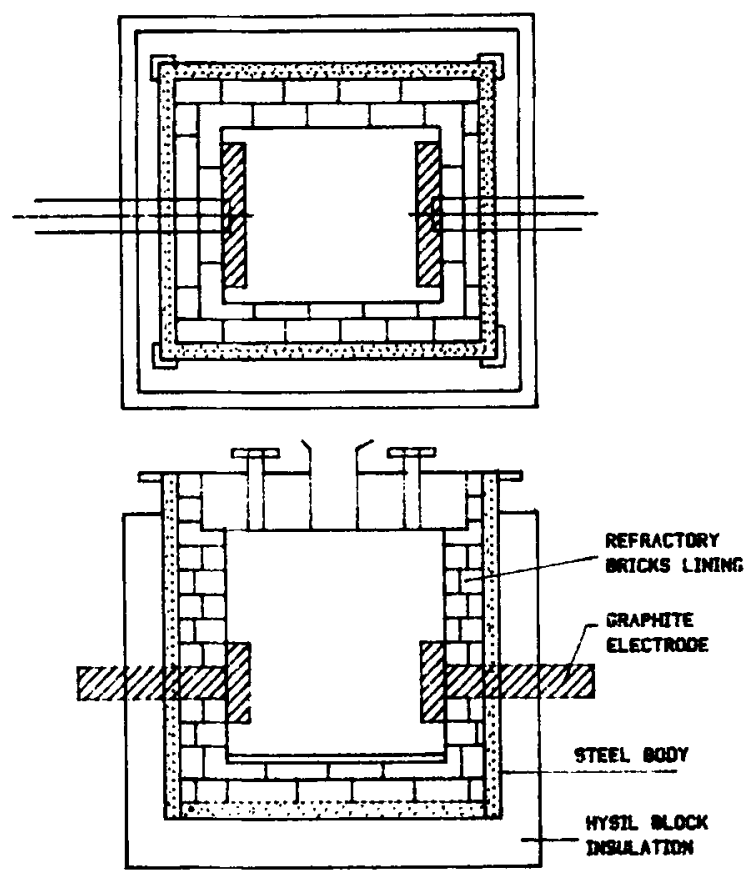

\section{SALtent FEATHES:}

1. Power Inevit os $\mathrm{KY}$

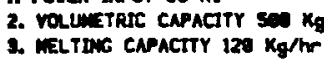

Figure 11. Schematic diagram of $\mathrm{MgCl}_{2}$ salt bath melting furnace.

cell both with a slight positive pressure or a negative pressure as desired. Care has been taken in the design to minimize the problem of bypass current which can result in a steep fall in current efficiency. The cell has been designed to operate at around 20 to $25 \mathrm{~V}$ with magnesium production estimated at around $300 \mathrm{~kg} /$ day.

An AC electrode-salt bath furnace (figure 11) has been designed, fabricated and installed adjacent to the cell to facilitate pre-melting of solid anhydrous magnesium chloride with arrangements for pressure transfer to the cell at regular intervals. The furnace is rated at $60 \mathrm{~kW}$ (Max voltage $35 \mathrm{~V}$, Max. current $1750 \mathrm{~A}$ ) and is capable of generating a molten feed of magnesium chloride at a rate of $100 \mathrm{~kg} / \mathrm{h}$.

A specially designed vacuum ladle with facility for pre-heating to about $750^{\circ} \mathrm{C}$ with an LPG burner will be used for receiving molten magnesium from the cell under vacuum and subsequent transfer into moulds under argon pressure.

Figure 12 shows the cell house at DMRL along with the electrode salt bath furnace, the multipolar cell and the vacuum ladle in their respective positions. All sub-systems have been tested and commissioned and integral operation is scheduled to commence shortly.

\section{Conclusions}

Titanium is an exceptional metal with a large potential for wide ranging industrial and engineering applications. India is rich in titanium minerals, especially ilmenite. While 


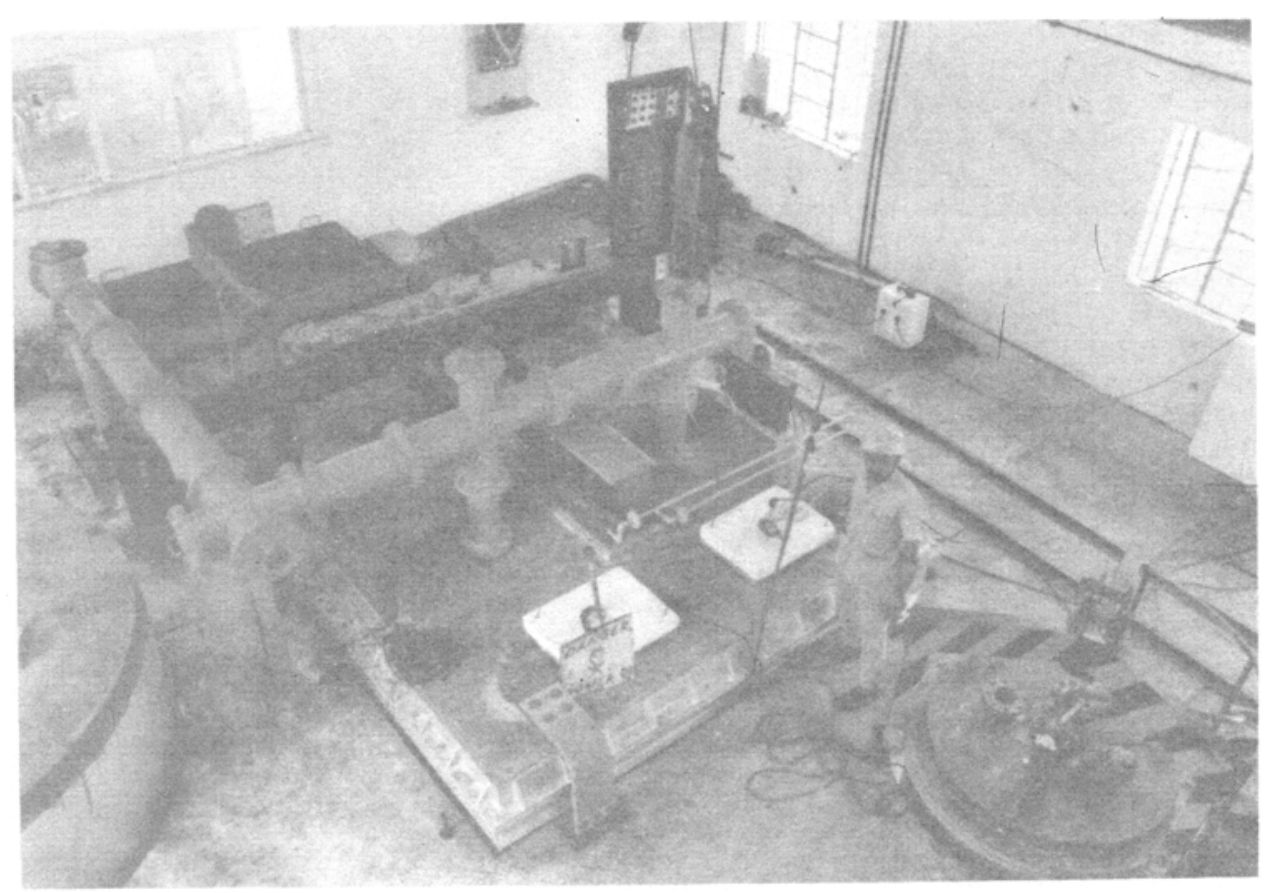

Figure 12. Cell house of DMRL.

on the one hand the rich mineral deposits are exploited for export, the country imports titanium sponge for manufacturing mill products. In addition several items in titanium are also imported as finished products. Insufficient demand and lack of indigenous technology for sponge production are cited as the main reasons for the present situation. With the opening up of the economy, the demand for titanium for a variety of industrial, engineering and consumer oriented applications is expected to grow sharply. Ready availability of indigenous sponge will itself catalyse rapid growth in demand not only in proven areas of application but also as replacement to stainless steels and copper base and nickel base alloys on considerations of life-cycle costs.

DMRL has pioneered industrial scale technology development for the production of titanium sponge initially in $2,000 \mathrm{~kg}$ batches by the conventional Kroll process and more recently by the combined process route in $4,000 \mathrm{~kg}$ batches. Technology for recycling the by-product magnesium chloride through the state-of-the-art multipolar cell is also under development. Time, therefore, is ripe for the country to establish its first commercial size integrated plant for titanium sponge production of about 1000 TPY capacity (along with a matching magnesium recycling plant) based on DMRL's efforts. DMRL is confident in providing a total technology package to interested enterpreneurs for this purpose.

\section{References}

Ahluwalia H S et al 1973 BARC Report No. 683, Bombay

Ginatta M V 1987 US Patent 4, 672, 121

Kulkarni A P, Sridhar Rao Ch and Sundaram CV 1969 Trans. IIM 22, 3, 10 
Kulkarni A P et al 1980 in Titanium '80 - Science and technology (eds) H Kimura and O Izuni (Warrendale, USA: Met. Soc. AIME) p. 1927

Noda T 1988a AMIE annual meeting (Phoenix: TMS Publications) pp 759-767

Noda T 1988b J. Metals 712

Roskill Economics of Titanium 1993 Eighth edition (London: Roskill Information Services)

Sekhar K N et al 1987 B. Electrochem. 3127

Sridhar Rao Ch, Kulkarni A P and Sundaram C V 1969 Trans. IIM 2210

Sridhar Rao Ch et al 1980 Trans. IIM 33275

Srivastava J N et al 1994 Quantification of gas lift action in magnesium electrolytic cells, Fifth int. symp. on advances in electrochemical science and technology (Karaikudi: CECRI)

Subramanyam R B et al 1990 High Temp. Mater. Process. 9195

Ullman's Encyclopaedia of Industrial Chemistry 1990 Vol. A 15 pp 559-579

Winter Ch Jr. 1956 US Patent 2,173,760 